\author{
ВАЛЕНТИНА АВРААМОВНА МАСЛОВА* \\ Витеб́ский государственный университет имени П.М. Машерова \\ Витебск, Беларусь

\section{ДУХОВНЫЙ КОД И ЕГО РОЛЬ НА ПУТИ ЕДИНЕНИЯ ВОСТОЧНЫХ СЛАВЯН}

\begin{abstract}
В статье, на материале славянских языков и культур, излагается концепция духовного кода как внутреннего субъъективного кода, нашедшего отображение в языке в виде системы духовных законов и духовных ценностей, а также нравственных ценностей и эталонов, которые выработались нацией в процессе ее формирования.
\end{abstract}

Ключевые слова: Лингвокультурология, коды культуры, духовный код, славянские языки и культуры

Лингвокультурология родилась в 90-е годы прошлого века в период отказа от монодисциплинарности, когда стало понятно, что невозможно получить новые знания в рамках традиционной лингвистики, что за ее рамками остается человек, его сознание, способ мышления, его культура.

Еще в 1995 году на Международной конференции «Лингвистика на исходе века» А.А. Леонтьев произнес «надгробное слово» «чистой» лингвистике». Язык, хотя и медленно, но переориентируется с исследования системы уровней на факт, событие, и тогда в центре внимания оказывается человек (языковая личность, по Ю.Н. Караулову). И хотя позиции традиционной лингвистики еще сильны, она неуклонно движется по пути интеграции с другими науками: появились когнитивная, гендерная, политическая, юридическая лингвистика, лингвокультурология, а сам XXI век постепенно становится веком конвергентного и трансдисциплинарного знания.

В XXI веке лингвокультурология также приобретает новый вектор развития (Шаклеин 2012). В ее недрах начитают развиваться новые подходы к описанию языка: язык как совокупность концептов лингвокуль-

*mvavit@tut.by 
туры (лингвоконцептология), язык как картина мира, язык как система кодов и др.

Для современной гуманитарной науки наиболее характерен переход от эксплицитного знания к глубинному. На рубеже тысячелетий стали искать подступы к глубинному познанию реальности. Примером могут служить работы академика Ю.С. Степанова «Концепты. Тонкая пленка цивилизации», «Мыслящий тростник», «Протей. Очерки хаотической эволюции» и др., в которых он выступал за творческий синтез интуиции, религии, науки и искусства, за их гармоничное слияние.

Как известно, одной из глубинных языковых категорий является смысл. Было установлено, что соединение знака со смыслом задает ту основу, на которой создается элементарная единица знания, а из этих единиц строится языковое сознание. Для данных единиц знания ученые используют различные термины - лингвокультуремы (В.В. Воробьев), культуремы (В.Г. Гак), логоэпистемы (В.Г. Костомаров, Е.М. Верещагин), информемы (В.В. Морковкин), концепт (Ю.С. Степанов) и др. Для нас наиболее приемлемым является термин коg.

Понятие «код» впервые появляется в технике связи и математике, затем проникает в биологию, физику, психологию, семиотику, психолингвистику, лингвокультурологию и в другие области знания. Однако, несмотря на широкое использование, это понятие не имеет четкого и однозначного определения, а потому размывается в разных направлениях и используется не терминологически, например, в целом ряде заголовочных конструкций публицистического, художественного и других дискурсов: «Код да Винчи», «Код ядерного убийцы» и др.

Традиционно в лингвистике данный термин является эквивалентом терминам знаковая сисиеема, язык. В ряде наук коg используется как синоним термину шuфр, например, в генетике. Кодирование понимается как шифровка, а декодирование - как расшифровка. Большинство лингвистов и семиотиков подчеркивают матричную природу кодирования, часто используя метафоры. Так, Р. Барт отождествляет коды с ячеистой сетью, забрасывая которую в текст можно вскрыть информацию разных уровней кодирования (Барт 2001: 20). В.В. Красных также уподобляет код культуры „сетке”, которую культура «набрасывает на окружающий мир, членит его, категоризует, структурирует и оценивает его» (Красных 2003: 232).

Мы подходим к пониманию кода с позиций лингвокультурологии, где данный термин тоже определяется по-разному. Например, В.Н. Телия, М.Л. Ковшова, Д.Б. Гудков, отождествляют культурные коды с вторичными знаковыми системами, а саму культуру понимают как пространство культурных кодов - вторичных знаковых систем (Ковшова 2008; 2012 и др.; Телия 2010). 
Мы понимаем культуру как ирросирансииво кульйурных коgов, а

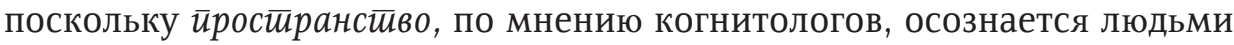
не через систему координат, а через отношения, существующие между объектами в пространстве (Кравченко 1996), мы представляем культурный код как глубинное культурное пространство, а используя метафору, - «контейнер», в котором разные языковые сущности получают различные культурные смыслы, заполняя собой и формируя тем самым код (Маслова 2013: 30).

Образная схема кониеейнера была впервые предложена Дж. Лакоффом и М. Джонсоном (Лакофф и Джонсон 2004). В русской лингвистике большой вклад в изучение метафоры конеиейнера внесли представители когнитивного направления Е.С. Кубрякова, Е.Е. Голубкова, Е.В. Рахилина и другие.

Итак, код позволяет составить целостное видение человека, языка, языкового сознания и культуры. Мы утверждаем, что любой язык может быть описан сквозь призму кодов, и это еще один способ описания языка, имеющий право на существование наряду с его системно-структурным описанием или описанием через совокупность концептов (Маслова, Пименова 2015).

Коды культуры с позиции лингвокультурологии - это специфический для каждой культуры набор способов социальной практики, свод ценностей и правил игры коллективного существования, выработанных в обществе и служащих для постижения мира человеком. Это совокупность реалий, выражающих определенные культурные смыслы и ценности. Коды могут включать в себя единицы, сами по себее не являющиеся знаками культуры, но которые, будучи включенными в ментальное пространство кода, могут становиться таковыми. Например, камень, лежащий на дороге, - это просто природная сущность (первосущность, по Аристотелю), но если его перенести на могилу, он становится знаком культуры памятником. Следовательно, объекты реального мира, помимо выполняемых ими прямых функций, приобретают в культуре знаковую функцию, т.е. становятся носителями дополнительной информации.

Различные авторы выдвигают свои основания для классификации кодов и выделяют разное их количество. Так, Р. Барт выделяет следующие коды: коннотативный, естественный, искусственный, исторический, культурный, смешанный или псевдореальный, вестиментарный, иконический, вербальный (Барт 2004).

Н.И. Жинкин в своей работе «Речь как проводник информации» говорит об устном коде, коде внутренней речи, буквенном коде, универсальном предметном, который требует передачи информации о всяком предмете и его качестве, а также фундаментальном, по его мнению, - текстовом (денотантном) коде (Жинкин 1998). 
В своей классификации лингвокультурных кодов мы исходим из мысли, что в качестве основы для классификации кодов может послужить лЮбой комплекс чувственно воспринимаемых реалий мира - космос, природа, животные, фауна, стихии, оружие, хозяйственная утварь, одежда, пищевые продукты питания, архитектурные сооружения и прочие артефакты, а также тело человека и ряд социокультурных явлений - культурные сценарии (трудовые процессы, праздненства, игры, состязания, битвы, шоу, шопинги и другие). Исходя из этих позиций и опираясь на исследования других лингвистов, мы выделяем такие коды культуры, как: космогонический (быть на сеgьмом небе), соматический (голова колонны, третий ілаз), пространственный (щирь gущи), временной (после войны), преgметный, или вещцный (от жилетки рукава), растительный (трава забвения, анютины глазки), зооморфный (львы, орлы в геральgике), прировно-ландшафтный (лес рук, море обиg), архитектурный (мосты оружбы, храм науки), пищевой, или гастрономический (хлеб насущзный, соль земли), gуховный (спасение gуши, милосерgие) и др.

С помощью любого кода можно описать в конкретной лингвокультуре весь репертуар ценностей, способов и норм поведения, действий и состояний человека. Таков, например, зооморфный код: глухой как тетерев (абсолютно глухой); гол как сокол (бедный); gошло как gо жирафа (о медленно понимающем человеке); козёл отпущения (человек, на которого постоянно сваливают ответственность за проступки, грехи других); ползти как улитка (медленно идти); коту поg хвост (о чемто, сделанном впустую); nоg мухой (о пьяном); меgвежья услуга (услуга, в результате которой получился противоположный результат); кот наплакал (очень мало) и т.д.

Итак, коды культуры образуют систему координат, которая задает эталоны и ценности культуры. Их реконструкция по материалам языка поможет воссоздать особенности восприятия и понимания явлений мира и человека - как самого себя, так и других. Коды «работают» на материале вторичной номинации, которая сформировались за счет переосмысления уже готовых единиц языка. Например, артерии как кровеносный сосуд, несущий кровь, и артерии страны как символ важности путей.

Особый интерес и сложность представляет gуховный коg, который есть главный путь перехода к глубинным знаниям. Это внутренний субъективный код, нашедший отображение в языке в виде системы духовных законов и духовных ценностей, а также нравственных ценностей и эталонов, которые выработались нацией в процессе ее формирования. Именно с помощью духовного кода может быть представлен «дух народа» (в понимании В. Гумбольдта). Пространство духовного кода куль- 
туры отражает духовно-нравственные запросы народа в конкретный исторический период, формирует некий идеал человека и общества определенной эпохи.

Говоря о духовном коде, мы имеем в виду, прежде всего, религиозный (сакральный) код, т.к. религиозность - одно из доминантных качеств русского национального характера, русской культуры. Более того, религией определяется целостность нации. Религия - это не просто вера в Бога, а особый способ осмысления народом и индивидом своего существования, своего места в мире.

Категории духа и духовности не относятся к собственно лингвистическим понятиям, а развиваются в науке о языке, исходя из опыта рефлексии над значениями ряда слов в различных языках и над их использованием в религиозно-философских контекстах.

Во всех славянских культурах существуют настоящие духовные личности, святые земли славянской (сербской - Иустин Попович, украинской - Амфилохий Почаевский, белорусской - Кирилл Туровский, русской - Тихон Задонский и др.), которые формировали не только православную, но и светскую культуру. Так, белорус Кирилл Туровский - проповедник, епископ, философ, писатель, который после смерти был причислен к лику святых. Его проповеди, молитвы, воззрения на мир и человека - это высокий уровень нравственности и святости. В. В. Колесов писал: «Пожалуй, вплоть до Державина в русской литературе не появлялся писатель такой силы, значительности и высоты нравственного чувства, как Кирилл - совесть своего нелегкого и бурного времени» (Колесов 1980).

К. Туровский стоял у истоков белорусской философской мысли. Обращение к проблемам бытия, добра и зла, поиск путей постижения истины, определение мудрости, прозрение души - вот основные вопросы, над которыми он думал. По К. Туровскому, душа прозревает только через приобщение к знаниям. Дух наследуется и генетически и путем научения. Безнравственный человек, считал он, не может быть мудрым: «В злохитрую душу не войдет премудрость, не в силах укорениться в сердце лукавом и оскверненном пьянством и блудом» (Туровский 1999: 5).

Изучение первоисточников - трудов наших духовных лидеров показывает нам путь единения, высвечивая наши общие христианские ценности: не убей, не украgи и т.д., основываясь на которых (они почти полностью утеряны европейскими народами!), мы ощущаем свое славянское братство. Общими для нас являются нравственные ценности (честь, совесть, достоинство, счастье, добро, зло, долг, справеgливость, одиночество, gружба, смысл жизни), религиозные (вера, Бог, закон Божий, возмезgие, благоgать, спасение, смирение и др.), эстетические (прекрасное, безобразное), правовые (закон, правопоряgок), социальные (се- 
мья, gети, материнство, отиовство, труя, брак), политические (мир, gемократия, толерантность) и др.

Итак, ядро духовного кода - это религиозные и нравственные ценности, но духовный код существует в двух ипостасях - сакральной и светской. Основные религиозные (сакральные) ценности, строящие сакральную ипостась духовного кода, мы находим в молитвах. Например, в молитве Пресвятой Богородице мы просим: просветить ум и очи сердечные, заступничества перед Богом, правильной веры, надежды, лЮбви нелицемерной, мужества в искушениях, терпения в злостраданиях, постоянства в молитвах, здравия, плодоносия земли, довольства житейских потреб, благословения Божьего, богохранимой стране мира и т.д.

Остальные ценности - светская ипостась духовного кода. Справедливости ради нужно отметить, что сакральное и светское в культуре и языке всегда трудно дифференцировать. Нравственный закон внутри нас, по Канту, - это присущее человеку свойство различения добра и зла, голос совести и внутреннее требование правды. Внимание к себе, самоанализ раскрывает человеку внутри себя целый мир, где действительно «Дьявол с Богом борется» (Достоевский). Совестиь - наиболее очевидное проявление нравственного закона, которое имеет и светскую, и сакральную ипостась.

Духовный код формируется не только через поучения наших святых отцов, но и через огромный лексический пласт, центром которого является церковная лексика, до сих пор искаженно представленная в современных словарях, кроме, пожалуй, словаря Скляревской. 70 лет атеизации общества нанесли значительный урон духовности и менталитету русского народа, о чем свидетельствуЮ негативные коннотации, закрепленные в словарях у таких лексем, как преgание, gъякон, божиться и др.

К христианской лексике следует отнести не только религиозно-философскую лексику (аскеза, бессмертие, благочестие, богохульство, грех, гор оость, гор gыня, греховность, gобродетель, яобродетельность, вера, воскресение, Бог и под.), но и слова, называющие всю небесную иерархию во главе с Богом, у Которого в Библии насчитывается более 500 имен. В книге Исаии (9:6) он именуется Чуgным, Советником, Богом крепким, Оти,ом вечности, Князем мира, Спасителем мира, Искупителем, Агнием Божим, Светом миру и др., а в Евангелии от Иоанна - Госпоgь Иисус Христос, Царь Царей, Госпоgь Госпоgствующих, Хлеб Жизни, Еgинороgный Сын, Воgа Жизни, а также Всевышници, Всеgержитель, Мессия, Твореи, и под. Это объясняется множественностью ситуаций, в которых Христос является участником и, соответственно, выполняет самые разные функции. Казалось бы, тождественные слова различаются в духовном коде, потому что в каждом из них актуализируется определенный семанти- 
ческий компонент. Так, имена Бог, Всевышници, Всеgержитель, Мессия, Твореи, Созgатель, Вышний, Всемогущий, Преgвечный, Госпоgь, Отеи, Небесный, Отеи, Спаситель, Спас, Христос, Богочеловек актуализируют различные признаки высшего существа: в именах Твореи, Созgатель репрезентируется идея творения мира, в именах Всеgержитель, Всемогущиц̆, Госпоgь - идея управления миром, в имени Преgвечный актуализирован временной компонент, т.е. имя репрезентирует идею вечного (бесконечного и безначального) существования Бога, в именах Вышний, Всевышний - актуализируется наивысшее место в небесной иерархии. Имена Отеи, Небесный, Отеи, содержат указание на вид отношения человека и Бога - отец и сын, Богочеловек - на сущность Бога, в котором сливаются человеческое и божественное; в именах Спаситель, Спас указывается на возможность спастись с его помощью и т.д.

К религиозной лексике относятся также Богороgии, Богоматерь, Пречистая, Присновева, апостоль, ангель, архангель, серафимы, херувимы и противников Бога (антихрист, бес, gьявол); слова, называющие поведение человека (благочестивый, богохульник, грешник, молитвенник, набонный, отшельник), религиозные тексты (Еваніелие, Библия, тропарь, nатерик, апокрифы), а также праздники (Рожgество, Пасха), обрядовую практику (крещение, отпевание, миропомазание), события Священной истории (исхоg, воскресение), ритуальные блюда (кутья, просфора, кулич), одежда (власянии, клобук, ряса, фелонь), предметы, используемые в религиозной практике (колокол, свеча, елей, лаgан, миро) и др.

Появились работы, в которых реконструируются и исследуются духовные концепты (Буевич 2014).

Русское слово в своих глубинах сакрально. Язык и религия представляют собой две формы отображения мира в сознании людей, две стихии в душе человека, два самых глубоких взаимосвязанных начала в человеческой культуре. Для русских характерна вера в слово как в непосредственное созерцание Божественной истины.

Язык - основной источник веры. Во-первых, вера заключена в самом языке: первая и главная функция языка древних, скорее всего, была сакральной. Во-вторых, вера репрезентирована с помощью языковых средств. Вера консервируется в языке и хранится в нем веками. Поэтому родной язык - носитель истины и источник народной мудрости, который формирует нас. «В начале было Слово...», именно Божественное Слово стало началом, источником энергийной силы, предшествующей человеку и создавшей его. Язык, по П. Флоренскому, - это свет божьей благодати, излитой на человека. Язык присутствует внутри нас, это наш «дом бытия» (М. Хайдеггер), он носитель и средство выражения истины и Божественной воли. 
Духовный код лингвокультуры формируется не только через слово, но и через огромный пласт духовной поэзии - от «Богогласников», С. Полоцкого и М. Ломоносова до поэтов наших дней (Ю. Кузнецов, М. Шлехов, Н. Карташева, К. Мозгалова и др.). Бог и христианские ценности были фундаментом русской поэзии на протяжении всего X1X века - от Пушкина до В. Соловьева и А. Блока. Например, у Нины Карташевой:

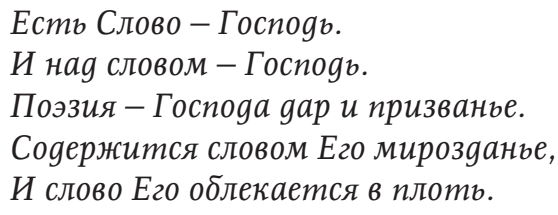

Высшая власть духа соединяется в творчестве поэтов с христианским миросозерцанием и христианскими идеалами добра и красоты. «Бог в культурном ареале, начиная с первых веков православия, был своеобразным вместилищем морали, гуманистических традиций, питаЮщих искусство, в том числе искусство слова» (Граудина, Кочеткова 2010: 26).

Таким образом, именно духовный код, наша общая вера, отображенная в языке и культуре, может стать фундаментом в укреплении славянского братства.

\section{ЛИТЕРАТУРА}

Барт P. S/Z. - М.: Эдиториал УРСС, 2001

Барт Р. Система моды: Статьи по семиотике культуры / Пер. с фр., вступ. ст. и сост. С.Н. Зенкина. - М.: Издательство Сабашниковых, 2004. - 512 с.

Буевич, А. А. Религиозный концепт «спасение» в русской культуре (на материале религиозного, философского и художественного дискурсов) / А. А. Буевич // Вестник РУДН. Серия: Теория языка. Семиотика. Семантика. № 2, 2014. - С.45-62.

Граудина Л.К., Кочеткова Г.И. Русское слово в лирике XIX века. - М.: Наука, Флинта, 2010.

Жинкин Н. И. Язык - речь - творчество: исследования по семиотике, психолингвистике, поэтике. - М.: Лабиринт, 1998. - 366 с.

Ковшова, М.Л. Анализ фразеологизмов и коды культуры / М.Л. Ковшова // Известия РАН. Серия литературы и языка . - 2008. - № 2. - Т. 67. - С. 60-65.

Ковшова М.Л. Лингвокультурологический метод во фразеологии. Коды культуры. М.: УРСС, 2012.

Колесов В.В. Из «Притч» и «Слова» Кирилла Туровского (Подготовка текста, перевод и комментарии В.В. Колесова) // Памятники литературы Древней Руси. Х11 век. - М., 1980. 
Красных В.В. Этнопсихолингвистика и лингвокультурология. - М.: 2003. - 283 С.

Кравченко А.В. Язык и восприятие. Когнитивные аспекты языковой категоризации. - Иркутск, 1996. - С. 34-41.

Лакофф Дж., Джонсон М. Метафоры, которыми мы живем / Дж. Лакофф, М. Джонсон. - M.: URSS, 2004.

Маслова В.А. Мир и человек сквозь призму спортивного кода // Новое в когнитивной лингвистике XX1 века: сборник научных статей / отв. ред. М.В. Пименова. - Киев: Издательский дом Д. Бураго, 2013 - С. 28-36.

Маслова В.А., Пименова М.В. Коды культуры в пространстве языка. Серия «Концептуальные и лингвальные миры», сер. 9. СПб., 2015, - 148 с.

Телия В. Н., Дорошенко А. В. Лингвокультурологическая гипотеза воспроизводимости языковых выражений // Язык. Ментальность. Культура. Материалы Международной научной конференции «ЖиводействуЮщая связь языка и культуры». Том 1. Москва-Тула 2010, с. 3-11.

Туровский К. Избранные произведения. Вып. 2. Гомель, 1999.

Шаклеин В.М. Лингвокультурология: традиции и инновации : монография / В.М. Шаклеин. - М. : Флинта, 2012. - 301 с.

Валентина Авраамовна Маслова

\section{ДУХОВНЫЙ КОД И ЕГО РОЛЬ НА ПУТИ ЕДИНЕНИЯ ВОСТОЧНЫХ СЛАВЯН}

\section{Резюме}

Любой язык может быть описан сквозь призму кодов, и это еще один способ описания языка, имеющий право на существование наряду с его системноструктурным описанием или описанием через совокупность концептов. Коды культуры с позиции лингвокультурологии - это специфический для каждой культуры набор способов социальной практики, свод ценностей и правил игры коллективного существования, выработанных в обществе и служащих для постижения мира человеком. Это совокупность реалий, выражающих определенные культурные смыслы и ценности. Особый интерес и сложность представляет духовный код, который есть главный путь перехода к глубинным знаниям. Это внутренний субъективный код, нашедший отображение в языке в виде системы духовных законов и духовных ценностей, а также нравственных ценностей и эталонов, которые выработались нацией в процессе ее формирования. Именно с помощью духовного кода может быть представлен «дух народа» (в понимании В. Гумбольдта). Пространство духовного кода культуры отражает духовнонравственные запросы народа в конкретный исторический период, формирует 
некий идеал человека и общества определенной эпохи. Именно духовный код, наша общая вера, отображенная в языке и культуре, может стать фундаментом в укреплении славянского братства.

Ключевые слова: лингвокультурология, коды культуры, духовный код, славянские языки и культуры 